\title{
molecules
}

ISSN 1420-3049

www.mdpi.com/journal/molecules

Article

\section{Luteolin Isolated from the Flowers of Lonicera japonica Suppresses Inflammatory Mediator Release by Blocking NF-кB and MAPKs Activation Pathways in HMC-1 Cells}

\author{
Ok-Hwa Kang ${ }^{1,2}$, Jang-Gi Choi ${ }^{1}$, John-Hwa Lee ${ }^{2}$ and Dong-Yeul Kwon ${ }^{1, *}$
}

1 Department of Oriental Pharmacy, College of Pharmacy, Wonkwang University, Wonkwang Oriental Medicines Research Institute, Jeonbuk 570-749, Korea; E-Mails: kangokhwa@daum.net (O-H.K.); jj0038@wku.ac.kr (J-G.C.)

2 College of Veterinary Medicine and Bio-Safety Research Institute, Chonbuk National University, Jeonju, 561-756, Korea; E-Mails: johnhlee@chonbuk.ac.kr (J-H.L.)

* Author to whom correspondence should be addressed; E-Mail: sssimi@wku.ac.kr; Tel.: +82-63-850-6802; Fax: 82-63-852-6802.

Received: 30 November 2009; in revised form: 7 January 2010 / Accepted: 12 January 2010 / Published: 18 January 2010

\begin{abstract}
Luteolin (3',4',5,7-tetrahydroxylflavone) is a plant flavonoid and pharmacologically active agent that has been isolated from several plant species. In the present study, the effect of luteolin from the flowers of Lonicera japonica on phorbol 12-myristate 13-acetate (PMA) plus A23187-induced mast cell activation was examined. Luteolin significantly inhibited the induction of inflammatory cytokines such as tumor necrosis factor (TNF)- $\alpha$, interleukin (IL)-8, IL-6 and granulocyte-macrophage colonystimulating factor (GM-CSF) by PMA plus A23187. Moreover, luteolin attenuated cyclooxygenase (COX)-2 expression and intracellular $\mathrm{Ca}^{2+}$ levels. In activated $\mathrm{HMC}-1$ cells, the phosphorylation of extra-signal response kinase (ERK 1/2) and c-jun $N$-terminal Kinase (JNK 1/2), but not p38 mitogen-activated protein kinase (p38 MAPK) were decreased by treatment of the cells with luteolin. Luteolin inhibited PMA plus A23187induced nuclear factor (NF)- $\kappa \mathrm{B}$ activation, I $\mathrm{\kappa B}$ degradation, and luciferase activity. Furthermore, luteolin suppressed the expression of TNF- $\alpha$, IL-8, IL-6, GM-CSF, and COX-2 through a decrease in the intracellular $\mathrm{Ca}^{2+}$ levels, and also showed a suppression of the ERK 1/2, JNK 1/2, and NF- $\kappa$ B activation. These results indicated that luteolin from
\end{abstract}


the flowers of Lonicera japonica exerted a regulatory effect on mast cell-mediated inflammatory diseases, such as RA, allergy disease and IBD.

Keywords: Lonicera japonica; pro-inflammatory cytokine; intracellular $\mathrm{Ca}^{2+}$; $\mathrm{NF}-\kappa \mathrm{B}$; MAPKs

\section{Introduction}

Mast cells are one of the major effecter cells in the immune response system. Activated mast cells release pro-inflammatory cytokines, such as TNF- $\alpha$, IL-6, IL-8, IL-13, GM-CSF, and inflammatory mediators including histamine, leukotrienes, serotonin, prostaglandin $\left(\mathrm{PG} \mathrm{E}_{2}\right.$ as well as $\mathrm{PGD}_{2}$ [1-3]. Cytokines, such as IL-6, TNF- $\alpha$, IL-8 and GM-CSF, are released in a coordinated network and play an important role in chronic inflammation. As such, the pattern of cytokine expression largely determines the nature and persistence of the inflammatory response [4]. TNF- $\alpha$ is preformed and stored in granules of mast cells or newly synthesized following mast cell activation; it is a multifunctional cytokine and an important mediator of the immune and inflammatory response. TNF- $\alpha$ is an autocrine stimulator as well as a potent inducer of other inflammatory cytokines, including IL-1 $\beta$, IL-6, IL-8 and GM-CSF [5,6]. IL-6 is a pro-inflammatory cytokine and a potent mediator of inflammatory processes [7]. GM-CSF also plays an important role in the development and perpetuation of inflammation [8]. A previous study reported that histamine induced GM-CSF production in human bronchial epithelial cells [9]. Cytokines produce their cellular effects by activation of various transcription factors such as AP-1 and NF- $\mathrm{BB}$. Furthermore, the expression of many of these cytokines and their receptors are upregulated by these transcription factors.

$\mathrm{Ca}^{2+}$ acts as a second messenger during cell activation. An increase in the levels of intracellular $\mathrm{Ca}^{2+}$ has been proposed to act as an essential trigger for mast cell activation [10,11]. It has also been reported that the release of intracellular $\mathrm{Ca}^{2+}$ from internal stores is required for MAPK activation [12]. Recently, studies showed the involvement of MAPK and NF- $\mathrm{BB}$ activation by $\mathrm{Ca}^{2+}$, with increased $\mathrm{Ca}^{2+}$ levels inducing the release of biological mediators including TNF- $\alpha$, IL-6 and IL-8 [13,14]. Moreover, NF- $\mathrm{KB}$ activation was reported to be required for the expression of many inflammatory proteins such as GM-CSF, TNF- $\alpha$, IL-6, COX-2 and inducible nitric oxide synthase (iNOS) [15]. Therefore, inhibition of NF- $\mathrm{KB}$ could reduce the expression of inflammatory genes and is a mechanism by which anti-inflammatory agents might elicit their anti-inflammatory effects [16].

Lonicera japonica Thunb.(Caprifoliaceae) is known in traditional Korean medicine as an antiinflammatory treatment. It has a strong scent typical of an aromatic medicinal plant, and its flowers are used to treat skin inflammations and wounds. Lonicera japonica was found to have anti-tumor effects in human lung carcinoma cells [17], and anti-allergic effects [18]. Flavonoids such as luteolin are ubiquitous plant secondary metabolites and have a variety of biological effects, including antiinflammatory and anti-allergic properties; some of these compounds are also known to inhibit the release of histamine from mast cells [19]. Luteolin was shown to inhibit pro-inflammatory cytokine production in vitro [20], and suppresses inflammation-associated gene expression by blocking the NF$\kappa \mathrm{B}$ and AP-1 activation pathway [21]. These reports suggest that the anti-inflammatory effect of 
luteolin isolated from the flowers of Lonicera japonica may be through potent inhibition of mast cell activation. However, no preexisting study has been reported on mast cell-mediated anti-inflammatory activity of luteolin isolated from the flowers of Lonicera japonica. Thus, as a part of our ongoing screening program to evaluate the anti-inflammatory potential of natural compounds, we investigated the in vitro anti-inflammatory activity of Lonicera japonica through activity-guided fractionation. Subsequently, the effects of luteolin isolated from the flowers of Lonicera japonica were evaluated on PMA plus A23187-induced pro-inflammatory mediators by inhibiting MAPKs and $\mathrm{I} \kappa \mathrm{B} \alpha / \mathrm{NF}-\kappa \mathrm{B}$ signal pathways in HMC-1 cells.

\section{Results and Discussion}

Many recent studies on plant-derived anti-inflammatory compounds have investigated the potential inhibitory effects of natural products using in vivo and in vitro systems. Luteolin, as a plant flavonoid, is an active oriental medicine ingredient that has been isolated from several plant species and used since ancient times to cure diseases such as inflammation, allergy and cancer. However, no report has been issued on the anti-inflammatory effects of luteolin isolated from the flowers of Lonicera japonica or on the mode of action of its active constituents.

In the present study, luteolin isolated from the flowers of Lonicera japonica was investigated for mast cell-mediated anti-inflammatory effects. To evaluate the potential effects of luteolin on the production of pro-inflammatory cytokines, we pretreated the cells with luteolin $(10$ and $50 \mu \mathrm{M})$ before stimulation with PMA $(50 \mathrm{nM})$ and A23187 $(1 \mu \mathrm{M})$ for $8 \mathrm{~h}$, and further analysis using ELISA. As shown in Figure 1, the levels of TNF- $\alpha$, IL-8, IL-6 and GM-CSF were considerably increased after stimulation with PMA plus A23187 in HMC-1. Pretreatment of cells with luteolin $(10$ and $50 \mu \mathrm{M})$ significantly inhibited the increase of these protein levels in a concentration-dependent manner. The maximal inhibition of TNF- $\alpha$, IL-8, IL-6 and GM-CSF production by luteolin $(50 \mu \mathrm{M})$ was approximately $87 \%, 86 \%, 78 \%$, and $46 \%$, respectively. Moreover, we examined the cytotoxicity of luteolin on HMC-1 cells using the MTT assay. Luteolin did not exhibit any cytotoxic effects up to $100 \mu \mathrm{M}$ (data not shown).

Next, the pro-inflammatory cytokine gene expression was then analyzed using RT-PCR and realtime RT-PCR (Figure 2). Enhanced TNF- $\alpha$, IL-8, IL-6 and GM-CSF mRNA expression induced by PMA plus A23187 was inhibited by pretreatment of cells with luteolin at a concentration of $50 \mu \mathrm{M}$. Pretreatment with $10 \mu \mathrm{M}$ of luteolin only slightly decreased the gene expression of TNF- $\alpha$ and IL-6, but not the other cytokines.

In a recent study, it was demonstrated that COX-2 played important roles in mast cell-mediated inflammation [22]. So, to determine the effect of luteolin on COX-2 protein and COX-2 mRNA expression induced by PMA plus A23187, we performed Western blot and RT-PCR analysis. The cells were pretreated with luteolin $(10$ and $50 \mu \mathrm{M})$ for $1 \mathrm{~h}$ and then treated with PMA plus A23187 for $10 \mathrm{~h}$. As shown in Figure 3, luteolin inhibited the PMA plus A23187-induced expression of COX-2 protein and mRNA levels. 
Figure 1. Effect of luteolin on production of pro-inflammatory cytokines in PMA plus A23187-induced HMC-1 cells.

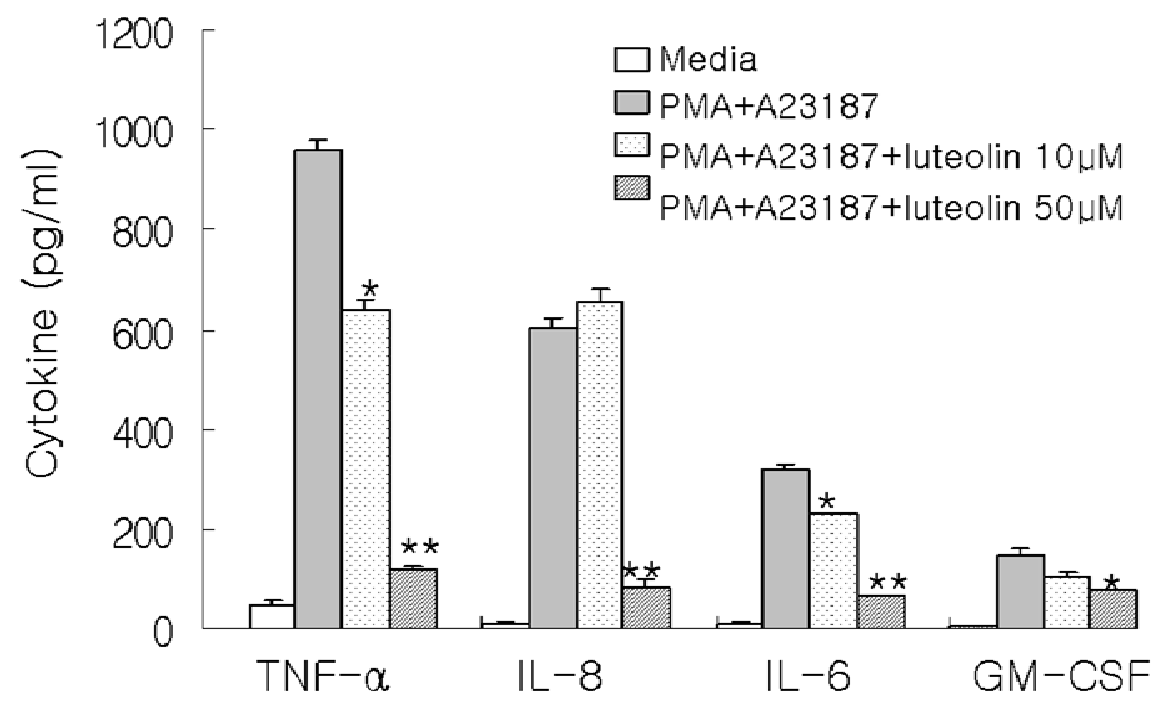

HMC-1 cells were pretreated with luteolin $(10$ and $50 \mu \mathrm{M})$ for $1 \mathrm{~h}$ prior to PMA+A23187 stimulation. The levels of TNF- $\alpha$, IL-8, IL-6, and GM-CSF were determined by ELISA. Each bar represents the mean \pm S.E.M. of three independent experiments. ${ }^{*} p<0.05, * * p<0.001$ compared to PMA+A23187-stimulated values.

Figure 2. Effect of luteolin on gene expression of pro-inflammatory cytokines in PMA plus A23187-induced HMC-1 cells.

A
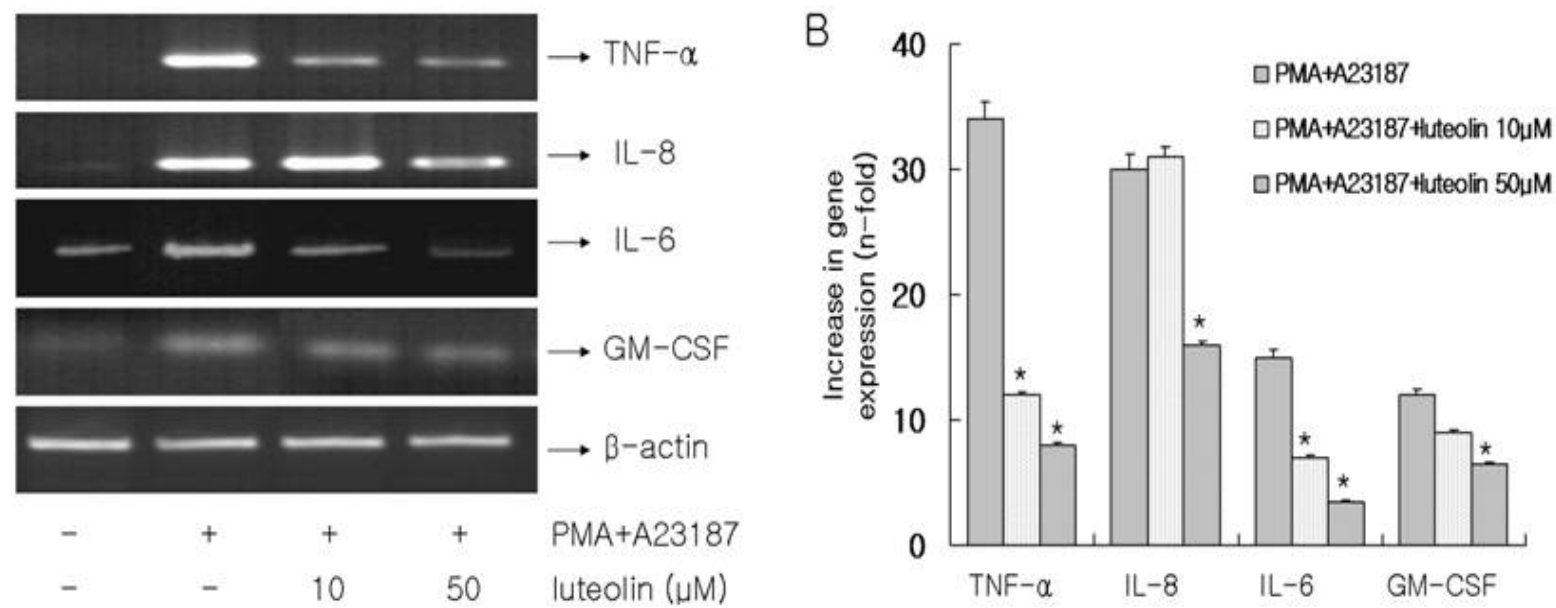

Cells were pretreated with luteolin $(10$ and $50 \mu \mathrm{M})$ for $1 \mathrm{~h}$ prior to PMA $(50 \mathrm{nM})+\mathrm{A} 23187(1 \mu \mathrm{M})$ stimulation for $6 \mathrm{~h}$. The mRNA expression level of TNF- $\alpha$, IL- 6 and IL-8 were determined by RTPCR (A) and real-time RT-PCR (B). Each bar represents the means \pm S.E.M. of three independent experiments. $* \mathrm{p}<0.05$, compared with PMA + A23187-stimulated values. 
Figure 3. Effect of luteolin on COX-2 protein and mRNA expression in PMA plus A23187-induced HMC-1 cells.
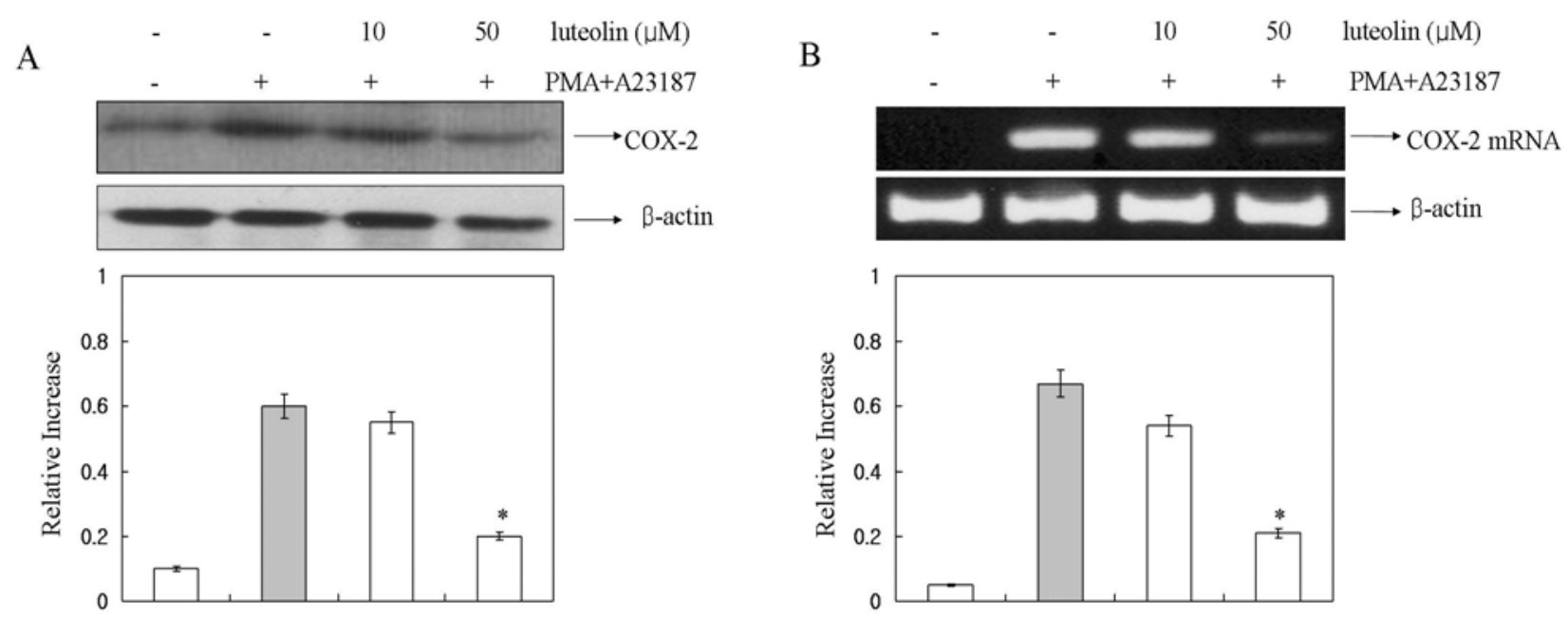

(A) Cells were pretreated with luteolin for $1 \mathrm{~h}$ prior to PMA $(50 \mathrm{nM})+\mathrm{A} 23187(1 \mu \mathrm{M})$ stimulation for $24 \mathrm{~h}$, and then expression of the COX-2 protein was analyzed by Western blot analysis. (B) Cells were pretreated with luteolin for $1 \mathrm{~h}$ prior to PMA $(50 \mathrm{nM})+\mathrm{A} 23187(1 \mu \mathrm{M})$ stimulation for $10 \mathrm{~h}$, and then expression of COX-2 mRNA was analyzed by RT-PCR. Values are presented as means \pm S.E.M. of three independent experiments. ${ }^{*} \mathrm{p}<0.05$ compared to PMA + A23187stimulated values, as analyzed by an image analyzer.

Calcium acts as a secondary messenger during cell activation [10]. An increase in the intracellular $\mathrm{Ca}^{2+}$ levels has been proposed to be an essential trigger for mast cell activation [23]. An increased intracellular $\mathrm{Ca}^{2+}$ level induces the release of biological mediators including TNF- $\alpha$, IL- 8 and IL- 6 [24]. It has also been reported that the release of intracellular $\mathrm{Ca}^{2+}$ from internal stores is required for MAPK activation [12]. A depletion of intracellular $\mathrm{Ca}^{2+}$ inhibited pro-inflammatory cytokine expression via NF-kB signaling pathway in RBL-2H3 cells [14]. From the results of the present study, we suggest that the inhibitory effects of luteolin on the expression of TNF- $\alpha$, IL-8, IL- 6 and GM-CSF levels is mediated by the reduction of intracellular $\mathrm{Ca}^{2+}$ in $\mathrm{HMC}-1$ cells. We also investigated the effect of luteolin on the intracellular levels of $\mathrm{Ca}^{2+}$, using confocal laser microscopy to detect the fluorescence signal coming from individual cells. The PMA plus A23187 treatment considerably increased the intracellular $\mathrm{Ca}^{2+}$ levels, but pretreatment of the cells with luteolin $(50 \mu \mathrm{M})$ inhibited this increase in intracellular $\mathrm{Ca}^{2+}$ levels (Figure 4).

In an attempt to evaluate the mechanisms underlying the effects of luteolin, we examined the potential effects of luteolin on activation of MAPKs. The stimulation of HMC-1 cells with PMA plus A23187 resulted in an increased phosphorylation of all three types of MAPKs, p38, JNK, and ERK, after 15-30 min (data not shown). As shown in Figure 5, luteolin attenuated PMA plus A23187induced phosphorylation of ERK $1 / 2$ and JNK $1 / 2$, but did not affect the phosphorylation of p38 MAPK (data not shown). The present study showed that luteolin inhibited the phosphorylation of ERK and JNK but not of p38 MAPK (Figure 5). Furthermore, luteolin demonstrated a greater level of inhibition of ERK and JNK-phosphorylation than the ERK 1/2 inhibitor (PD98059) and JNK 1/2 
inhibitor (SP600125). These data suggested that luteolin inhibited pro-inflammatory cytokine production and intracellular $\mathrm{Ca}^{2+}$ release via inhibition of ERK and JNK activation.

Figure 4. Effect of luteolin on intracellular calcium levels.

A
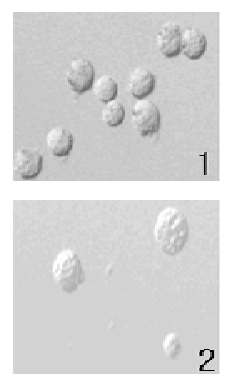

2

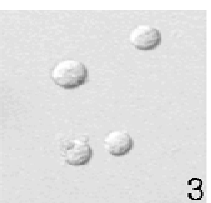

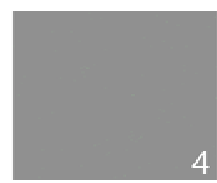

Blank

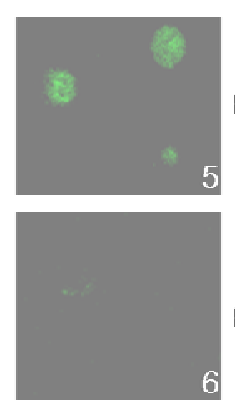

B

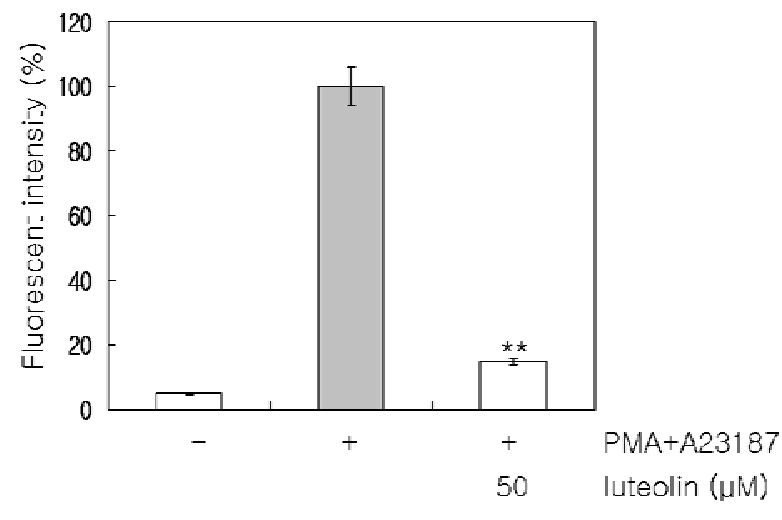

Cells were pretreated with luteolin for $1 \mathrm{~h}$ before the stimulation with PMA $(50 \mathrm{nM})+\mathrm{A} 23187$ $(1 \mu \mathrm{M})$. (A) The fluorescent image (1-3) was analyzed by confocal microscopy (4-6). Confocal images of HMC-1 cells were stained with fluo-3/AM. (B) The intensity of intracellular calcium was measured in three independent experiments. ${ }^{* *} \mathrm{p}<0.001$ compared to PMA + A23187-stimulated values.

Figure 5. Effect of luteolin on activation of MAPKs.

A
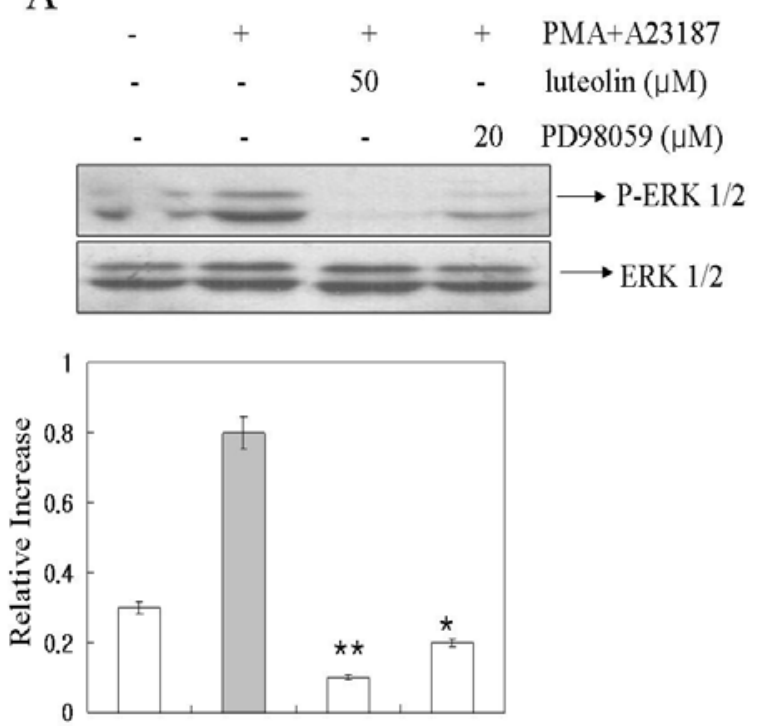

B
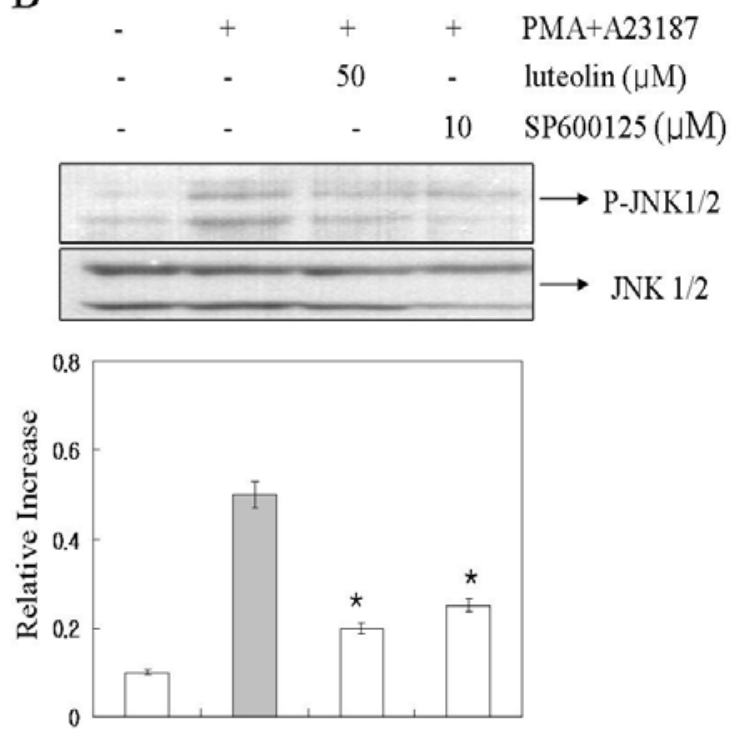

After pretreatment with luteolin for $1 \mathrm{~h}, \mathrm{HMC}-1$ cells were stimulated by PMA $(50 \mathrm{nM})$ and A23187 $(1 \mu \mathrm{M}) 30 \mathrm{~min}$ for MAPK activation. Phosphorylation of ERK1/2 (A) and JNK 1/2 (B) were analyzed by Western blot. The ERK inhibitor (PD 98059, $20 \mu \mathrm{M})$ and JNK inhibitor $(\mathrm{SP} 600125,10 \mu \mathrm{M})$ were used as a positive control. Values are presented as means \pm S.E.M. of three independent experiments. ${ }^{* *} \mathrm{p}<0.001,{ }^{*} \mathrm{p}<0.05$ compared to PMA + A23187-stimulated values, as analyzed by an image analyzer. 
To evaluate the mechanism by which luteolin affected the gene expression of pro-inflammatory cytokines, we examined the effects of luteolin on NF- $\kappa$ B activation. The expression of the proinflammatory cytokines tested in this study is known to be regulated by a transcription factor, NF- $\mathrm{KB}$ [25]. Stimulation of HMC-1 cells with PMA plus A23187 induced the degradation of I $\mathrm{B} \alpha$ and promoted the nuclear translocation of p65 NF- $\kappa \mathrm{B}$ after $2 \mathrm{~h}$ of incubation (Figure 6A). Luteolin inhibited the PMA plus A23187-induced degradation of $\mathrm{I} \kappa \mathrm{B} \alpha$ as well as the nuclear translocation of p65 NF- $\kappa$ B.

In order to confirm these results, we examined the possible effects of luteolin on the NF- $\mathrm{B}$ dependent gene reporter assay (Figure $6 \mathrm{~B}$ ). We transiently transfected HMC-1 cells with the pNF- $\mathrm{BB}$ luciferase reporter vector and pRL-TK vector and incubated the transfected cells with PMA plus A23187 in the presence or absence of luteolin. As shown in Figure 6B, the PMA plus A23187 treatment increased the reporter gene expression but this increased activity was significantly decreased by treatment with luteolin $(50 \mu \mathrm{M})$. The PDTC (NF- $\kappa$ B inhibitor) used as a positive control. This implies that luteolin might inhibit COX-2 expression through suppression of NF- $\kappa \mathrm{B}$ activation in HMC-1.

Figure 6. Effect of luteolin on the activation of NF- $\mathrm{BB}$ in $\mathrm{HMC}-1$ cells.
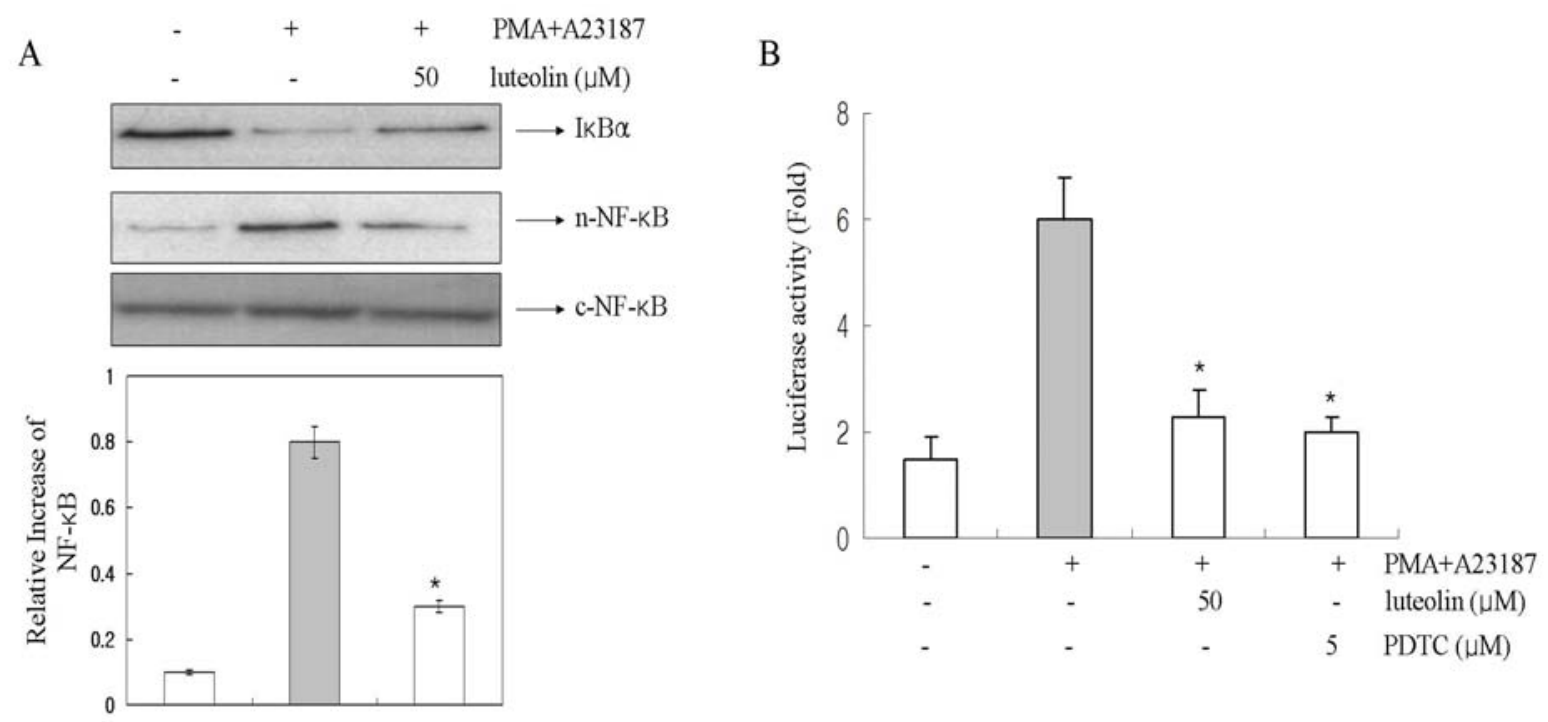

Cells were pretreated with luteolin for $1 \mathrm{~h}$ prior to PMA $(50 \mathrm{nM})$ and A23187 $(1 \mu \mathrm{M})$ stimulation. (A) I $\kappa \mathrm{B}$ degradation and NF- $\kappa \mathrm{B}$ translocation were assayed by Western blot (n-NF- $\kappa \mathrm{B}$, nucleus

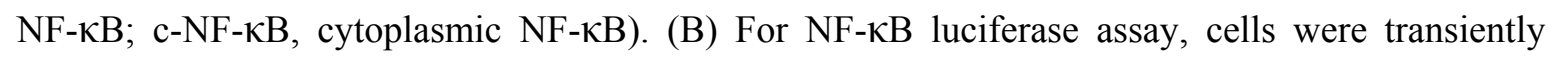
transfected with the NF- $\kappa$ B luciferase reporter construct or pRL-TK control vector. NF- $\kappa B-$ dependent transcriptional activity was determined by luciferase activity assay. The NF- $\kappa \mathrm{B}$ inhibitor (PDTC, $5 \mu \mathrm{M}$ ) was used as a positive control. * ${ }^{*}<0.05$ compared to PMA + A23187-stimulated values, as analyzed by an image analyzer.

Mast cells contain potent mediators, including histamine, heparin, proteinases, leukotrienes, and multifunctional cytokines; these molecules potentially contribute to the inflammatory processes and also play an important role [26]. Mast cell-derived pro-inflammatory cytokines, particularly TNF- $\alpha$, IL-8, IL-6 and GM-CSF have a critical biological role in allergic inflammation. In this study, we 
demonstrated that luteolin suppressed the expression of TNF- $\alpha$, IL-8, IL-6 and GM-CSF in PMA plus A23187-induced HMC-1 cells. These data indicated the anti-inflammatory effect of luteolin as a potent inhibitor of mast cell activation. Also, we tested the effects of luteolin on COX-2 expression and MAPK phosphorylation together with intracellular $\mathrm{Ca}^{2+}$ release in HMC-1 cells. The results indicated that luteolin reduced pro-inflammatory cytokine production, COX-2 expression and intracellular $\mathrm{Ca} 2+$ release via the inhibition of MAPK activation.

Recently, a number of published studies have indicated the interference of luteolin with NF- $\mathrm{B}$ [21]. Because this transcription factor is strongly linked to inflammatory and immune responses, we postulate that luteolin mediates its effects at least partly through suppression of NF- $\mathrm{KB}$ activation. Although NF- $\mathrm{BB}$ activation is regulated by MAPKs through multiple mechanisms, accumulating evidence indicates that NF- $\mathrm{BB}$ activation is modulated by MAPKs that induce site-specific

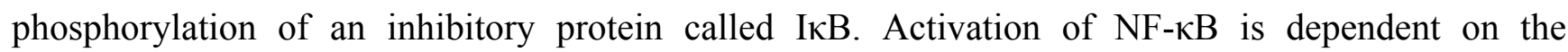
degradation of $\mathrm{I} \kappa \mathrm{B} \alpha$, an endogenous inhibitor that binds to NF- $\kappa \mathrm{B}$ in the cytoplasm [27]. So, the role of NF- $\mathrm{KB}$ activation is important for the regulation of cytokine production in inflammatory condition. Expression of the TNF- $\alpha$, IL-6, IL-8 and GM-CSF genes are dependent on the activation of transcription factor $\mathrm{NF}-\mathrm{\kappa B}$ in mast cells. This implies that luteolin might inhibit the expression of inflammatory mediators through the suppression of NF- $\kappa$ B activation and I $\kappa$ B degradation in HMC-1. Luteolin was shown to decrease the degradation of $\mathrm{I} \kappa \mathrm{B} \alpha$ and nuclear translocation of p65 NF- $\kappa \mathrm{B}$ in PMA plus A23187-stimulated mast cells. This demonstrated that luteolin inhibited the PMA and A23187-induced TNF- $\alpha$, IL-6, IL-8, GM-CSF and COX-2 expression through a decrease in the intracellular levels of $\mathrm{Ca}^{2+}$, ERK $1 / 2$, JNK 1/2, as well as activation of NF- $\kappa \mathrm{B}$.

\section{Experimental}

\subsection{Reagents}

PMA, the calcium ionophore A23187 (calcymycin; $\mathrm{C}_{29} \mathrm{H}_{37} \mathrm{~N}_{3} \mathrm{O}_{6}$ ), PD98059, SP600125, SB203580 and 3-[4,5-dimetylthiazol-2-yl]-2,5-diphenyltetrazolium bromide (MTT) were purchased from the Sigma Chemical Co. (St. Louis, MO, USA). Iscove's modified Dulbecco's medium (IMDM) was obtained from Gibco BRL (Grand Island, NY, USA); anti-human TNF- $\alpha$, IL-6, IL-8, and GM-CSF antibodies, the biotinylated anti-human TNF- $\alpha$, IL-6, IL-8, and GM-CSF antibodies, and recombinant human TNF- $\alpha$, IL-6, IL-8, and GM-CSF were purchased from BD PharMingen (San Diego, CA, USA); the NF- $\kappa \mathrm{B}$, and $\mathrm{I} \kappa \mathrm{B}$ antibodies from Santa Cruz Biotechnology (Santa Cruz, CA, USA); Lipofectamine $^{\mathrm{TM}} 2000$ was obtained from Invitrogen (Carlsbad, CA, USA), the NF- $\kappa$ B Luciferase Reporter vector from Panomics Inc; and the Dual-Luciferase ${ }^{\circledR}$ Reporter Assay System from Promega (Madison, WI, USA). SYBR Premix Ex TaqTM was purchased from Takara Bio (Shiga, Japan).

\subsection{Plant materials}

The flowers of Lonicera japonica purchased from the Daehak Hanyak kuk Oriental drug store (Iksan, Korea), were authenticated by Dr. D.Y. Kwon. A voucher specimen (No.08-030) was deposited in the Laboratory of Herbology, College of Pharmacy, Wonkwang University, Iksan, Korea. 


\subsection{Isolation of luteolin}

The $\mathrm{MeOH}$ extracts were partitioned with organic solvents of different polarities to yield $n$-hexane, EtOAc, $n-\mathrm{BuOH}$ and $\mathrm{H}_{2} \mathrm{O}$ fractions, in sequence. The EtOAc fraction of each plant was subjected to silica gel chromatography with $\mathrm{CH}_{2} \mathrm{Cl}_{2}-\mathrm{MeOH}$ (lower layers, by volume, $30: 1 \rightarrow 1: 1,100 \% \mathrm{MeOH}$, gradient) as the solvents to yield the Lonicera japonica luteolin. The structure of the compound was determined by its physico-chemical and spectral data (LC-MS, 1D and 2D NMR) which were in agreement with those reported in the literature [28, 29].

\subsection{Cell culture}

The HMC-1 cells were grown in IMDM and supplemented with $100 \mathrm{U} / \mathrm{mL}$ of penicillin, $100 \mu \mathrm{g} / \mathrm{mL}$ of streptomycin, and $10 \%$ fetal bovine serum (FBS) at $37{ }^{\circ} \mathrm{C}$ in $5 \% \mathrm{CO}_{2}$ with $95 \%$ humidity. The HMC-1 cells were treated with luteolin $(10 \mu \mathrm{M}$ to $50 \mu \mathrm{M})$ for $1 \mathrm{~h}$. The cells were then stimulated with $50 \mathrm{nM}$ of PMA plus $1 \mu \mathrm{M}$ of $\mathrm{A} 23187$ and incubated at $37^{\circ} \mathrm{C}$ for the indicated time periods.

\subsection{MTT assay}

For the MTT colorimetric assay of cell survival, we used a method described by Kang et al. [30]. Cell aliquots were seeded $\left(3 \times 10^{5}\right)$ in microplate wells and incubated with $20 \mu \mathrm{L}$ of an MTT solution $\left(5 \mathrm{mg} / \mathrm{mL}\right.$ ) for $4 \mathrm{~h}$ at $37{ }^{\circ} \mathrm{C}$ under $5 \% \mathrm{CO}_{2}$ and $95 \%$ air. This was followed by the addition of $250 \mu \mathrm{L}$ of DMSO to extract the MTT formazan. An automatic microplate reader was used to read the absorbance of each well at $540 \mathrm{~nm}$.

\subsection{Cytokine assay}

The HMC-1 cells were pretreated with various concentrations of luteolin $(10$ to $50 \mu \mathrm{M})$ for $1 \mathrm{~h}$ before PMA plus A23187-stimulation. We then used the enzyme-linked immunosorbent assay (ELISA) method to assay the culture supernatants for the TNF- $\alpha$, IL-8, IL-6 and GM-CSF protein levels. To measure the cytokines, we used a modified ELISA method by Kang et al. [31].

\subsection{RNA isolation, reverse transcription (RT) analysis}

Using a GeneAll ${ }^{\mathrm{R}}$ RiboEx RNA extraction kit (GeneAll Biotechnology, Republic of Korea), we isolated total RNA from HMC-1 cells in accordance with the manufacturer's specifications. The concentration of total RNA in the final eluate was determined by spectrophotometry. The total RNA $(2.0 \mu \mathrm{g})$ was heated at $65{ }^{\circ} \mathrm{C}$ for $10 \mathrm{~min}$ and then cooled on ice. A cDNA synthesis kit (iNtRON Biotech, Republic of Korea) was used for $90 \mathrm{~min}$ at $37^{\circ} \mathrm{C}$ to reverse-transcribe each sample to cDNA. Primer sequences for TNF- $\alpha$, IL-6, IL-8, GM-CSF, COX-2 and $\beta$-actin were used for PCR analysis as described previously [32]. The PCR products increased as the concentration of RNA increased. Finally, the products were electrophoretically resolved on a $2.0 \%$ agarose gel and visualized by staining with ethidium bromide. 


\subsection{Real-time RT-PCR}

The levels of TNF- $\alpha$, IL-6, IL-8, GM-CSF and $\beta$-actin mRNA were measured with the real-time reverse transcription (RT)-PCR method using SYBR green. Total RNA was extracted from the cells with an RNeasy ${ }^{\circledR}$ Mini kit (Qiagen Inc., Valencia, CA, USA). Aliquots $(1 \mu \mathrm{g})$ of total RNA were used for RT, using a PrimeScriptTM RT reagent kit (Takara Bio, Shiga, Japan) and a Smart cycler ${ }^{\circledR}$ II System Takara Bio, Shiga, Japan). The RT reaction was performed in total volume was $20 \mu \mathrm{L}$ using a SYBR Premix Ex TaqTM (Takara Bio); $2 \mu \mathrm{L}$ of cDNA sample was used as a template. Their sequences are shown in Table 1. Cycling was started with an activation step at $95{ }^{\circ} \mathrm{C}$ for $10 \mathrm{~s}$, and amplification program was repeated 45 times (denaturation, $95{ }^{\circ} \mathrm{C}$ for $5 \mathrm{~s}$; annealing/extension, $60^{\circ} \mathrm{C}$ for $20 \mathrm{~s}$ ) with fluorescence measurement at $72^{\circ} \mathrm{C}$.

The fluorescence of the SYBR green dye was determined as a function of the PCR cycle number. In order to confirm amplification specificity, the PCR products from each primer pair were subjected to a melting curve analysis. The $\Delta \mathrm{CT}$ values $\left(\mathrm{C}_{\mathrm{t}}=\right.$ cycle threshold value $)$ for the housekeeping gene ( $\beta$-actin) and the target gene (TNF- $\alpha$, IL-6, IL- 8 and GM-CSF) were calculated by subtracting the experiment group (PMA+A23187+luteolin) from the control (nonstimulated value). The relative expression of the target gene was calculated on the basis of $2^{-\Delta(\Delta \mathrm{Ct})}$. The $\Delta(\Delta \mathrm{Ct})$ values were calculated by subtracting the drug treated (PMA $+\mathrm{A} 23187+$ luteolin) $\Delta \mathrm{Ct}$ from the control (PMA+ A23187) $\Delta \mathrm{Ct}$. The primer sequences for target genes are described in Table 1.

Table 1. Sequences of oligonucleotide primers designed for real-time PCR.

\begin{tabular}{cccc}
\hline & Forward (5'-3' orientation) & Reverse (5'-3' orientation) & Accession no. \\
\hline hTNF- $\alpha$ & GACAAGCCTGTAGCCCATGTTGA & CAGCCTTGGCCCTTGAAGA & NM_000594.2 \\
hIL-6 & AAGCCAGAGCTGTGCAGATGAGTA & TGTCCTGCAGCCACTGGTTC & NM_000600.1 \\
hIL-8 & ACACTGCGCCAACACAGAAATTA & TTTGCTTGAAGTTTCACTGGCATC & NM_00584.2 \\
& & & \\
hGM- & ACCATGATGGCCAGCCACTAC & GTGATAATCTGGGTTGCACAGGAA & NM_000758 \\
CSF & & & \\
$\beta$-actin & ATTGCCGACAGGATGCAGAAG & ATGGAGCCACCGATCCACA & NM_0016142 \\
\hline
\end{tabular}

The primers pairs were designed using Primer Express ${ }^{\circledR}$ software.

\subsection{Fluorescent measurements of the intracellular $\mathrm{Ca}^{2+}$ level}

The intracellular $\mathrm{Ca}^{2+}$ values were obtained from a single cell using Fluo-3/AM, the fluorescent $\mathrm{Ca}^{2+}$-sensitive indicator. The cells were incubated with $4 \mu \mathrm{M}$ Fluo-3/AM at $37^{\circ} \mathrm{C}$ for $30 \mathrm{~min}$, and then washed with PBS. After addition of the culture medium, the temperature was maintained at $37{ }^{\circ} \mathrm{C}$ for $10 \mathrm{~min}$, and then the cells were viewed using confocal laser scanning microscope (Olympus, Japan). The Fluo-3 loaded cells were illuminated with the $488 \mathrm{~nm}$ line of an argon laser and the emitted fluorescence was collected through a $20 \times$ water-immersion objective and by setting the confocal pinhole to $2 \mu \mathrm{M}$. The intensity of fluorescence was detected using one of two photomultipliers. To obtain a good spatial image, three successive frames were collected for each cell. The intracellular $\mathrm{Ca}^{2+}$ level was evaluated by its fluorescent intensity [33]. 


\subsection{Preparation of cytoplasmic and nuclear extracts}

Nuclear and cytoplasmic extracts were prepared as described elsewhere [30]. Briefly, after activating the cells for the time periods indicated, $5 \times 10^{6}$ cells were washed with ice-cold PBS and centrifuged at $15,000 \times \mathrm{g}$ for $1 \mathrm{~min}$. The cells were then resuspended in $40 \mu \mathrm{L}$ of a cold hypotonic buffer (10 mM Hepes/KOH, $2 \mathrm{mM} \mathrm{MgCl}$, $0.1 \mathrm{mM}$ EDTA, $10 \mathrm{mM} \mathrm{KCl}, 1 \mathrm{mM}$ DTT, and $0.5 \mathrm{mM}$ PMSF, $\mathrm{pH}$ 7.9). The cells were allowed to swell on ice for 15 min after which they were lysed gently with $2.5 \mu \mathrm{L}$ of $10 \%$ Nonidet P (NP)-40. The lysate was centrifuged at $15,000 \times \mathrm{g}$ for $3 \mathrm{~min}$ at $4{ }^{\circ} \mathrm{C}$. The supernatant was collected and used as the cytoplasmic extract. The nuclear pellets were gently resuspended in $40 \mu \mathrm{L}$ of cold saline buffer $(50 \mathrm{mM}$ HEPES/KOH, $50 \mathrm{mM} \mathrm{KCl}, 300 \mathrm{mM} \mathrm{NaCl}$, $0.1 \mathrm{mM}$ EDTA, 10\% glycerol, $1 \mathrm{mM}$ DTT, and 0.5 mM PMSF, pH 7.9) and left for $20 \mathrm{~min}$ on ice. After centrifuging at $15,000 \times \mathrm{g}$ for $15 \mathrm{~min}$ at $4{ }^{\circ} \mathrm{C}$ aliquots of the supernatent containing nuclear proteins were frozen in liquid nitrogen and stored at $-70{ }^{\circ} \mathrm{C}$ until further analysis. The bicinchoninic acid protein assay (Sigma, St. Louis, MO, USA) was used for protein quantitation.

\subsection{Western blot analysis}

HMC- 1 cells $\left(5 \times 10^{6}\right.$ cells/well $)$ were stimulated with PMA $(50 \mathrm{nM})$ plus A23187 $(1 \mu \mathrm{M})$. Cell lysates were then prepared in a sample buffer containing sodium dodecyl sulfate (SDS). The samples were heated at $95{ }^{\circ} \mathrm{C}$ for $5 \mathrm{~min}$ and briefly cooled on ice. Following a centrifugation step at $15,000 \times \mathrm{g}$ for $5 \mathrm{~min}$, the proteins in the cell lysates were separated by $10 \%$ SDS-polyacrylamide gel electrophoresis (SDS-PAGE) and transferred to a nitrocellulose membrane. The membrane was then blocked with 5\% skim milk in PBS-Tween-20 for $1 \mathrm{~h}$ at room temperature and then incubated with anti-NF- $\kappa \mathrm{B}$, and $\mathrm{I} \kappa \mathrm{B}$. After washing the blot in PBS-Tween-20 three times, the blot was incubated with a secondary antibody for $1 \mathrm{~h}$ and then antibody-specific proteins were visualized using an enhanced chemiluminescence detection system in accordance with the recommended procedure (Amersham Corp., Newark, NJ, USA). The each protein levels were quantities with an image analyzer (FC-26WL, Vilber Lourmat, Marne-La-Vallee, France).

\subsection{Transient transfection and a luciferase assay}

For the transfection, HMC-1 cells were seeded $\left(1 \times 10^{7}\right)$ in a $100 \mathrm{~mm}$ culture dish. Lipofectamine ${ }^{\mathrm{TM}}$ 2000 (Invitrogen, Carlsbad, CA, USA) was used to transiently transfect pNF- $\kappa$ B luciferase reporter vector and pRL-TK control vector constructs into HMC-1 cells. In brief, the cells were incubated at $37{ }^{\circ} \mathrm{C}$ in a $5 \% \mathrm{CO}_{2}$ incubator for $48 \mathrm{~h}$, and then, the transfected HMC-1 cells were plated and stimulated with PMA plus A23187. Luteolin was added $1 \mathrm{~h}$ before stimulation. Four hours after stimulation, the cells were harvested and washed in cold PBS before lysing in a $500 \mu \mathrm{L}$ lysis buffer (Dual-Luciferase ${ }^{\circledR}$ Reporter Assay System; Promega). After vortex mixing and centrifugation at $12,000 \times \mathrm{g}$ for $3 \mathrm{~min}$ at $4{ }^{\circ} \mathrm{C}$, the supernatant was stored at $-70{ }^{\circ} \mathrm{C}$ until further analysis. For the luciferase assay, $20 \mu \mathrm{L}$ of cell extract was mixed with $100 \mu \mathrm{L}$ of the luciferase assay reagent at room temperature. To measure the luciferase activity, a luminometer (1420 luminescence counter, Perkin Elmer) was used in accordance with the manufacturer's protocol. All the transfection experiments were 
performed independently at least three times, showing similar results. The relative luciferase activity was defined as the ratio of firefly luciferase activity to renilla luciferase activity.

\subsection{Statistical analysis}

Statistical significances were compared between each treated group and analyzed by the Student's $t$-test. The data from the experiments are presented as means \pm S.E.M. The numbers of independent experiments assessed are given in the figure legends.

\section{Conclusions}

Luteolin regulated the production of TNF- $\alpha$, IL-6, IL-8 and GM-CSF in PMA plus A23187stimulated HMC-1 cells. Luteolin also decreased COX-2 expression and intracellular $\mathrm{Ca}^{2+}$ release. Furthermore, luteolin inhibited the ERK 1/2, JNK 1/2, and NF- $\mathrm{BB}$ pathway. Therefore, the regulation of the NF- $\kappa \mathrm{B}$ signal pathway by luteolin isolated from the flowers of Lonicera japonica in HMC-1 cells is a potentially attractive and characteristic probe for studying mast cell-mediated inflammatory diseases, such as IBD, RA, and allergy disease.

\section{Acknowledgements}

This work was supported by the grant of Post-doc. Program, Chonbuk National University (2008).

\section{References and Notes}

1. Zhu, Z.; Homer, R.J.; Wang, Z.; Chen, Q.; Geba, G.P.; Wang, J.; Zhang, Y.; Elias, J.A. Pulmonary expression of interleukin-13 causes inflammation, mucus hypersecretion, subepithelial fibrosis, physiologic abnormalities, and eotaxin production. J. Clin. Invest. 1999, 103, 779-788.

2. Royer, B.; Varadaradjalou, S.; Saas, P.; Gabiot, A.C.; Kantelip, B.; Féger, F.; Guillosson, J.J.; Kantelip, J.P.; Arock, M. Autocrine regulation of cord blood-derived human mast cell activation by IL-10. J. Allergy. Clin. Immunol. 2001, 108, 80-86.

3. Stassen, M.; Müller, C.; Arnold, M.; Hültner, L.; Klein-Hessling, S.; Neudörfl, C.; Reineke, T.; Serfling, E.; Schmitt, E. IL-9 and IL-13 production by activated mast cells is strongly enhanced in the presence of lipopolysaccharide: NF-kappa B is decisively involved in the expression of IL-9. J. Immunol. 2000, 166, 4391-4398.

4. Barnes, P.J.; Adcock, I. Anti-inflammatory actions of steroids: molecular mechanisms. Trends. Pharmacol. Sci. 1993, 14, 436-441.

5. Arend, W.P.; Dayer, J.M. Inhibition of the production and effects of interleukin-1 and tumor necrosis factor alpha in rheumatoid arthritis. Arthritis. Rheum. 1995, 38, 151-160.

6. Butler, D.M.; Maini, R.N.; Feldmann, M.; Brennan, F.M. Modulation of proinflammatory cytokine release in rheumatoid synovial membrane cell cultures. Comparison of monoclonal anti TNF-alpha antibody with the interleukin-1 receptor antagonist. Eur. Cytokine. Netw. 1995, 6, 225-230.

7. Erchler, W.B.; Keller, E.T. Age-associated increased interleukin-6 gene expression, late-life diseases, and frailty. Annu. Rev. Med. 2000, 51, 245-270. 
8. Manning, A.M.; Bell, F.P.; Rosenbloom, C.L.; Chosay, J.G.; Simmons, C.A.; Northrup, J.L.; Shebuski, R.J.; Dunn, C.J.; Anderson, D.C. NFkappa B is activated during acute inflammation in vivo in association with elevated endothelial cell adhesion molecule gene expression and leukocyte recruitment. J. Inflamm. 1995, 45, 283-296.

9. Takizawa, H.; Ohtoshi, T.; Kikutani, T.; Okazaki, H.; Akiyama, N.; Sato, M.; Shoji, S.; Ito, K. Histamine activates bronchial epithelial cells to release inflammatory cytokines in vitro. Int. Arch. Allergy. Immunol. 1995, 108, 260-267.

10. Rasmussen, H.; Goodman, D.B. Relationships between calcium and cyclic nucleotides in cell activation. Physiol. Rev. 1977, 57, 421-509.

11. White, J.R.; Pluznik, D.H.; Ishizaka, K.; Ishizaka, T. Antigen-induced increase in protein kinase C activity in plasma membrane of mast cells. Proc. Natl. Acad. Sci. USA 1985, 82, 8193-8197.

12. Crossthwaite, A.J.; Hasan, S.; Williams, R.J. Hydrogen peroxide-mediated phosphorylation of ERK1/2, Akt/PKB and JNK in cortical neurones: Dependence on $\mathrm{Ca}(2+)$ and PI3-kinase. $J$. Neurochem. 2002, 80, 24-35.

13. Kim, M.S.; Lim, W.K.; Park, R.K.; Shin, T.; Yoo, Y.H.; Hong, S.H.; An, N.H.; Kim, H.M. Involvement of mitogen-activated protein kinase and NF-kappaB activation in $\mathrm{Ca}^{2+}$-induced IL-8 production in human mast cells. Cytokine 2005, 32, 226-233.

14. Jeong, H.J.; Hong, S.H.; Lee, D.J.; Park, J.H.; Kim, K.S.; Kim, H.M. Role of Ca(2+) on TNFalpha and IL-6 secretion from RBL-2H3 mast cells. Cell. Signal. 2002, 14, 633-639.

15. Pastore, S.; Fanales-Belasio, E.; Albanesi, C.; Chinni, L.M.; Giannetti, A.; Girolomoni, G. Granulocyte macrophage colony-stimulating factor is overproduced by keratinocytes in atopic dermatitis. Implications for sustained dendritic cell activation in the skin. J. Clin. Invest. 1997, 99, 3009-3017.

16. Newton, R.; Kuitert, L.M.; Bergmann, M.; Adcock, I.M.; Barnes, P.J. Evidence for involvement of NF-kappaB in the transcriptional control of COX-2 gene expression by IL-1beta. Biochem. Biophys. Res. Commun. 1997, 237, 28-32.

17. Leung, H.W.; Hour, M.J.; Chang, W.T.; Wu, Y.C.; Lai, M.Y.; Wang, M.Y.; Lee, H.Z. P38associated pathway involvement in apoptosis induced by photodynamic therapy with Lonicera japonica in human lung squamous carcinoma CH27 cells. Food. Chem. Toxicol. 2008, 46, 3389-3400.

18. Chan, B.C.; Hon, K.L.; Leung, P.C.; Sam, S.W., Fung, K.P.; Lee, M.Y.; Lau, H.Y. Traditional Chinese medicine for atopic eczema: PentaHerbs formula suppresses inflammatory mediators release from mast cells. J. Ethnopharmacol. 2008, 30, 85-91.

19. Foreman, J.C. Mast cells and the actions of flavonoids. J. Allergy. Clin. Immunol. 1984, 73, 769-774.

20. Xagorari, A.; Papapetropoulos, A.; Mauromatis, A; Economou, M.; Fotsis, T.; Roussos, C. Luteolin inhibits an endotoxin-stimulated phosphorylation cascade and proinflammatory cytokine production in macrophages. J. Pharmacol. Exp. Ther. 2001, 296, 181-187.

21. Chen, C.Y.; Peng, W.H.; Tsai, K.D.; Hsu, S.L. Luteolin suppresses inflammation-associated gene expression by blocking NF-kappaB and AP-1 activation pathway in mouse alveolar macrophages. Life. Sci. 2007, 30, 1602-1614. 
22. Kim, S.J.; Jeong, H.J.; Choi, I.Y.; Lee, K.M.; Park, R.K.; Hong, S. H.; Kim, H.M. Cyclooxygenase-2 inhibitor SC-236 [4-[5-(4-chlorophenyl)-3-(trifluoromethyl)-1-pyrazol-1-1] benzenesulfonamide] suppresses nuclear factor-kappaB activation and phosphorylation of $\mathrm{p} 38$ mitogen-activated protein kinase, extracellular signal-regulated kinase, and c-Jun N-terminal kinase in human mast cell line cells. J. Pharmacol. Exp. Ther. 2005, 314, $27-34$.

23. White, D.H.; Pluzmik, K.; Ishizaka, T. Antigen-induced increase in protein kinase C activity in plasma membrane of mast cells. Proc. Nati. Acad. Sci. USA 1986, 82, 8139-8197.

24. H. K. Joo1; S. K. Lee; H. S. Kim; Y. J. Song; G. Kang; J. B. Park; K. H. Lee; E. J. Cho; J. H. Lee; I.W. Seong; S. H. Kim; C.H. Cho; B. H. Jeon. Korean Red Ginseng Extract inhibits Tumor Necrosis Factor-alpha-induced Monocyte Adhesion in the Human Endothelial Cells. J. Ginseng. Res. 2008, 32, 244-249.

25. Azzolina, A.; Bongiovanni, A.; Lampiasi, N. Substance P induces TNF-alpha and IL-6 production through NF kappa B in peritoneal mast cells. Biochim. Biophys. Acta 2003, 1643, 75-83.

26. Bradding, P.; Holgate, S.T. Immunopathology and human mast cell cytokines. Crit. Rev. Oncol. Hematol. 1999, 31, 119-133.

27. Lee, F.S.; Hagler, J.; Chen, Z.J.; Maniatis, T. Activation of the IkappaB alpha kinase complex by MEKK1, a kinase of the JNK pathway. Cell 1997, 88, 213-222.

28. Choi, C.W.; Jung, H.A.; Kang, S, S.; Choi, J. S. Antioxidant Constituents and a New Triterpenoid Glycoside from Flos Lonicera. Arch. Pharm. Res. 2007, 30, 1-7.

29. Lu, Y.H.; Ji, Z.; Qi, J.X.; Du, C.P.; Chen, R.C.; Wu, S.C. Synthesis of luteolin and kaempferol. Acta Pharmaceut. Sinica 1980, 15, 447-481.

30. Kang, O.H.; Lee, G.H.; Choi, H.J.; Park, P.S.; Chae, H.S.; Jeong, S.I.; Kim, Y.C.; Sohn, D.H.; Park, H.; Lee, J.H.; Kwon, D.Y. Ethyl acetate extract from Angelica Dahuricae Radix inhibits lipopolysaccharide-induced production of nitric oxide, prostaglandin E2 and tumor necrosis factor-alphavia mitogen-activated protein kinases and nuclear factor-kappaB in macrophages. Pharmacol. Res. 2007, 55, 263-270.

31. Kang, O.H.; Chae, H.S.; Choi, J.H.; Choi, H.J.; Park, P.S.; Cho, S.H.; Lee, G.H.; So, H.Y.; Choo, Y.K.; Kweon, O.H.; Kwon, D.Y. Effects of the Schisandra fructus water extract on cytokine release from a human mast cell line. J. Med. Food. 2006, 9, 480-486.

32. Salgame, P.; Abrams, J.S.; Clayberger, C.; Goldstein, H.; Convit, J.; Modlin, R.L.; Bloom, B.R. Differing lymphokine profiles of functional subsets of human CD4 and CD8 T cell clones. Science 1991, 254, 279-282.

33. Grynkiewicz, G.; Poenie, M.; Tsien, R.Y. A new generation of Ca2+ indicators with greatly improved fluorescence properties. J. Biol. Chem. 1985, 260, 3440-3450.

Sample Availability: Available from the corresponding author.

(C) 2010 by the authors; licensee Molecular Diversity Preservation International, Basel, Switzerland. This article is an open-access article distributed under the terms and conditions of the Creative Commons Attribution license (http://creativecommons.org/licenses/by/3.0/). 